\title{
Effects of defaunation on digestion and growth, in sheep receiving a mixed diet (fresh Digitaria decumbens grass and concentrate) at four protein to energy ratios
}

\author{
Maguy EUGÈNE ${ }^{\mathrm{a}}$, Harry ARCHIMÈDE ${ }^{\mathrm{a} *}$, Jean-Louis WEISBECKER ${ }^{\mathrm{a}}$, \\ Fred PERIACARPIN ${ }^{\mathrm{a}}$, George SAMINADIN ${ }^{\mathrm{a}}$, Daniel SAUVANT ${ }^{\mathrm{b}}$ \\ a INRA, Unité de Recherches Zootechniques, Prise d'eau, Petit-Bourg, 97170 Guadeloupe, France \\ b UMR-INRA-INAPG, Physiologie de la Nutrition et Alimentation, 16 rue Claude Bernard, \\ 75231 Paris Cedex 05, France
}

(Received 11 April 2002; accepted 22 January 2004)

\begin{abstract}
The effects of defaunation on growth and digestion were measured on sheep consuming four mixed diets (D1 to D4) of Digitaria decumbens grass and concentrate, with different protein to energy ratios. The protein digestible in the intestine (protein French feeding system, PDI) to energy (Forage unit, energy French feeding system) levels (P/E) in the diets were 80 (D1), 100 (D2), 120 (D3) and 140 (D4). Conventional and ciliate-free animals were conducted in parallel in $4 \times 4$ Latin square designs. First, two Latin square designs were conducted with 20 faunated lambs and 20 defaunated lambs to measure the average daily gain. In addition, two other Latin square designs were conducted with 8 conventional mature rams and 8 ciliate-free mature rams to measure digestion parameters. There was no effect of the diet on the average daily gain (ADG) of the lambs. The ADG of faunated lambs was significantly lower $(P<0.05)$ compared with defaunated lambs with the D2 diet $\left(153.7\right.$ vs. 211.6 , s.e. $\left.=13.0 \mathrm{~g} \cdot \mathrm{d}^{-1}\right)$. The feed conversion ratio was higher with conventional lambs compared with ciliate-free lambs with the D2 diet $\left(7.2 \mathrm{vs.} 4.7\right.$, s.e. $=1.6 \mathrm{~g} \cdot \mathrm{g}^{-1}$, $P<0.05)$. The same trend was observed with the energy conversion ratio for the $\mathrm{D} 2$ diet $(6.0 \mathrm{vs}$. 4.0, s.e. $\left.=0.710^{-3} \mathrm{UFL} \cdot \mathrm{g}^{-1}, P<0.05\right)$. The differences of ADG between conventional and ciliatefree lambs can be explained by the higher supply of protein in ciliate-free animals when the energy was not the first limiting factor for microbial and animal growth. Duodenal non-ammonia nitrogen (NAN) flow was significantly increased $(P<0.01)$ by defaunation $\left(144\right.$ vs. 172 , s.e. $\left.=5.5 \mathrm{~g} \mathrm{NAN} \cdot \mathrm{d}^{-1}\right)$. However, the differences of NAN flow, observed between faunated and defaunated rams, were only significant $(P<0.01)$ with the D3 diet. The duodenal microbial N flow was significantly $(P<0.01)$ higher with ciliate free rams compared with conventional ones, consuming diets D2 and D3. A better microbial synthesis efficiency and a higher nitrogen digestion for the defaunated animals, explain the differences in nitrogen availability between the animals.
\end{abstract}

digestion / growth / defaunation / sheep

* Corresponding author: archi@ antilles.inra.fr 
Résumé - Les effets de la défaunation sur la digestion de rations mixtes (herbe de Digitaria decumbens et concentré) et la croissance de moutons. Quatre régimes mixtes (D1 à D4) composés de fourrage Digitaria decumbens et de concentré, différenciés par le rapport protéine / énergie dans le régime, ont été constitués. Le niveau de protéines digestibles dans l'intestin (Système PDI français) / énergie (UF, unité fourragère du Système français) de la ration (P/E) était de 80 (D1), 100 (D2), 120 (D3) et 140 (D4). Des animaux conventionnels et des animaux dépourvus de protozoaires ont été utilisés dans des dispositifs en carré latin $4 \times 4$ menés en parallèle. D'une part, deux dispositifs en carré latin ont été conduits avec 20 agneaux faunés et 20 agneaux défaunés afin de mesurer leur gain de poids moyen quotidien (GMQ). D'autre part, deux autres dispositifs en carré latin ont été conduits en parallèle avec 8 béliers adultes conventionnels et 8 béliers dépourvus de protozoaires, afin de mesurer les paramètres de la digestion. Il n'y a pas eu d'effet de la ration sur la croissance des agneaux. Le GMQ des agneaux faunés a été significativement $(P<0,05)$ inférieur à celui des agneaux défaunés avec la ration D2 $\left(153,7\right.$ vs. 211,6 , s.e. $\left.=13,0 \mathrm{~g} \cdot \mathrm{j}^{-1}\right)$. L'indice de transformation de l'aliment a été supérieur pour les agneaux faunés comparativement aux agneaux défaunés pour la ration D2 (7,2 vs. 4,7 , s.e. $\left.=1,6 \mathrm{~g} \cdot \mathrm{g}^{-1}, P<0,05\right)$. La même tendance a été observée en ce qui concerne l'indice de transformation de l'énergie pour la ration D2 $(6,0$ vs. 4,0, s.e. = $\left.0,710^{-3} \mathrm{UF} \cdot \mathrm{g}^{-1}, P<0,05\right)$. Les différences de croissance entre les agneaux faunés et défaunés ont été expliquées par une plus grande disponibilité en protéines des animaux défaunés quand l'énergie n'était pas le premier facteur limitant de la croissance microbienne ou animale. Le flux duodénal d'azote non ammoniacal a été significativement augmenté par la défaunation (144 vs. 172, s.e. = $5,5 \mathrm{~g}$ d'N non ammoniacal $\left.\cdot \mathrm{j}^{-1}, P<0,01\right)$. Cependant, les différences de flux d'azote non ammoniacal observées entre béliers faunés et défaunés n'ont été significatives $(P<0,01)$ qu'avec la ration D3. Les flux d'azote microbien ont été significativement $(P<0,01)$ plus élevés pour les animaux défaunés comparativement aux animaux faunés avec, les rations D2 et D3. Une meilleure efficacité de la synthèse microbienne ajoutée à une plus grande digestion de l'azote en faveur des animaux défaunés ont expliqué les différences de disponibilité en azote entre ces animaux.

\section{digestion / croissance / défaunation / ovin}

\section{INTRODUCTION}

The different literature reviews, of many studies dealing with the effect of defaunation on animal performance, do not lead to the same results $[4,12,15,24]$. Some of the studies report negative effects of defaunation on average daily gain of the animals [1, $9,11,22]$ whereas, others indicate the absence of any effect or a positive effect [3, $5,7,13]$. The nature of the diet may strongly account for the different results observed [24]. The main conclusion is that no effect is observed with forage with high nitrogen contents whereas a positive effect could appear with forage with low nitrogen [6]. Nevertheless, this statement fails to explain the positive effect of defaunation observed with mixed diets in some results of the literature $[6,14,16,31]$. The rumen fermentable nitrogen to fermentable energy ratio would mainly be responsible for the observed results. Moreover, the total amounts of protein and energy supplies relative to the animal's requirements would be another major factor of variation. The objective of this study was (1) to evaluate the effect of defaunation on the growth of lambs consuming mixed diets formulated to provide increasing rumen fermentable (protein / energy) ratio in the diet; (2) to point out some parameters of the digestion which may explain the observed effects of defaunation.

This study was conducted with a tropical grass usually described as poor forage with a low protein to energy ratio. In this context, defaunation should be a way to improve ruminant nutrition. The forage was complemented with four levels of concentrate to generate a large gradient of protein to energy values. 


\section{MATERIALS AND METHODS}

\subsection{Location}

The research was carried out at the animal experimental station of the National Institute of Agricultural Research, in Guadeloupe, in the French West Indies, (latitude $16^{\circ} 16^{\prime} \mathrm{N}$, and longitude $61^{\circ} 30^{\prime}$ ). Average temperatures ranged from $21^{\circ} \mathrm{C}$ to $31^{\circ} \mathrm{C}$. The rainfall on the experimental site is $3000 \mathrm{~mm}$ a year. Two trials were conducted: a growth and a digestion trial. The objective of the growth trial was to evaluate the effect of defaunation on the growth of the lambs consuming a mixed diet. The objective of the second trial was to find out the digestive factors explaining the results observed in the first trial.

\subsection{Experimental animals, diets and design}

\subsubsection{Growth trial}

\subsubsection{Animals}

Twenty Black Belly (Ovin Martinik) lambs (average live weight: $28.3 \pm 5.9 \mathrm{~kg}$ ) were defaunated by isolation from their dams, one day after their birth [15]. They received colostrum, artificial milk, concentrate, and fresh grass. They were weaned at 3 months simultaneously with 20 fellow lambs living under their dams.

\subsubsection{Diet}

For all diets the forage was a 28 days of age Digitaria decumbens grass regrowth given ad libitum (minimum of 10\% refusals). The diets had different protein to energy ratios. In diet 1 (D1), the forage was supplemented with $600 \mathrm{~g}$ of maize. In diets D2, D3, and D4 the same forage was complemented with $350 \mathrm{~g}(50 \mathrm{~g}$ Soya meal + $300 \mathrm{~g}$ of maize), $230 \mathrm{~g}$ ( $80 \mathrm{~g}$ of Soya meal + $150 \mathrm{~g}$ of maize) and $100 \mathrm{~g}$ (100 g of Soya meal) of concentrate respectively. The
Table I. Organic matter (OM), crude protein (CP), neutral detergent fibre (NDF) and acid detergent fibre (ADF) contents $\left(\mathrm{g} \cdot \mathrm{kg}^{-1} \mathrm{DM}\right)$ of the diets ${ }^{1}$.

\begin{tabular}{lcccc}
\hline Diets & D1 & D2 & D3 & D4 \\
\hline Chemical composition & (\%DM) & & & \\
OM & 96 & 95 & 94 & 93 \\
$\mathrm{CP}(\mathrm{N} \times 6.25)$ & 9.8 & 12.1 & 13.9 & 14.2 \\
$\mathrm{NDF}$ & 34.8 & 46.7 & 53.4 & 63.8 \\
$\mathrm{ADF}$ & 15.2 & 21.7 & 25.5 & 31.4 \\
$\mathrm{ADL}$ & 1.9 & 2.5 & 2.8 & 3.4 \\
$\mathrm{PDIN} / \mathrm{UFL}\left(\mathrm{g} \cdot \mathrm{UFL}^{-1}\right)$ & 80 & 100 & 120 & 140 \\
FP/FE index $(\%)$ & 8.8 & 11.9 & 14.4 & 18.1 \\
\hline
\end{tabular}

${ }^{1}$ Mixed diets composed of fresh Digitaria decumbens grass (28-day age of regrowth) and 4 concentrate mixtures (Soya meal + ground maize); the diets were formulated to provide 4 protein / energy ratios of 80,100,120 and $140 \mathrm{~g}$ PDIN/UFL on diet D1, D2, D3 and D4 respectively.

PDIN: protein digestible in the intestine from microbial origin, UFL: French feed unit.

FP/FE is the fermentable protein / fermentable energy index estimated as the protein truly digested in the rumen / the organic matter truly digested in the rumen.

chemical compositions of the diets are presented in Table I. The protein to energy ratio, expressed as PDI/UF, is an easy criteria in the French animal nutrition system to determine the animal nutritional requirements. The PDI (Protéines Digestibles dans l'Intestin grêle) estimates the quantity of amino nitrogen $\mathrm{N} \times 6.25$ absorbed in the small intestine from the dietary protein which has escaped fermentation in the rumen, and the nitrogen protein arising from that fermentation [34]. The feed unit (UF) represents the energy value of the feeds. One UF is equivalent to the energy value of $1 \mathrm{~kg}$ of standard barley [35]. In the text we refer to the PDIN, protein digestible in the intestine from microbial origin, and to the UFL, "Unité Fourragère Lait". The fermentable protein to fermentable energy index (FP/FE) of the diets was estimated as the protein truly digested in the rumen / the 
organic matter truly digested in the rumen. Water and mineralised salt blocks were available ad libitum. The blocks' composition was $\left(\mathrm{g} \cdot \mathrm{kg}^{-1}\right)$ : $\mathrm{Ca}(60.0), \mathrm{P}(20.0), \mathrm{Mg}$ (10.0), Na (280.0), Zn (17.5), Mn (5.5), Fe (1.5), I (0.03), Co (0.03) and Se (0.01).

\subsubsection{Experimental design}

Faunated and defaunated rams, isolated with a punch cloth, were housed in individual pens in the same room. Four groups of 5 defaunated lambs and 4 groups of 5 faunated lambs were constituted after allotting the animals according to weight at the beginning of the trial, and individual average daily gain between 1 and 2 months of age. After weaning, all lambs received a similar diet (fresh grass ad libitum and $200 \mathrm{~g}$ of growth concentrate) during an adaptation period of one month. Then the faunated and defaunated animals were conducted simultaneously in two $4 \times 4$ latin square designs. Each period, lasting one month, was composed of 15 days of adaptation to the diet and 15 days of measurement. The forage was distributed in two meals at $7 \mathrm{~h}$ and $19 \mathrm{~h}$ and all the concentrate was given at $7 \mathrm{~h}$. All lambs were fed the 4 diets formulated to generate a large gradient of protein to energy ratio. The amounts of energy of these 4 diets should allow an average daily gain (ADG) higher than $200 \mathrm{~g} \cdot \mathrm{d}^{-1}$, whereas the amount of protein could only permit an ADG of $150 \mathrm{~g} \cdot \mathrm{d}^{-1}$ (unpublished data). Our hypothesis was that for the ciliate free animals the lack of protein in the diet would be compensated by an increase in microbial protein flow due to defaunation. The maximum growth observed in the intensive system, with the Ovin Martinik lambs was $250 \mathrm{~g} \cdot \mathrm{d}^{-1}$. Fermentable nitrogen and energy were not limiting factors for microbial growth with these diets [2]. The feed and energy conversion ratios (FCR and $\mathrm{ECR}$ ) were calculated as follows:

$$
\text { FCR = DMI / ADG; ECR = UFI / ADG }
$$

DMI: dry matter intake, ADG: average daily gain, UFI: energy intake in feed units.

\subsubsection{Digestion trial}

\subsubsection{Animals}

Sixteen Black Belly (Ovin Martinik) rams (average live weight: $45.1 \pm 7.7 \mathrm{~kg}$, 2 years old), each fitted with a rumen and a duodenum $\mathrm{T}$ piece surgically implanted cannula, were used in this trial. Half of them were defaunated using a milk diet by a method adapted from Fujihara et al. [20]. During the defaunation process, the diet was gradually changed from a fresh young grass to milk powder diet within 10 days. Then the animals were fed milk alone for 7 days. The diet was gradually changed from milk to fresh grass. The milk powder was mixed with water $\left(400 \mathrm{~mL}, 37^{\circ} \mathrm{C}\right)$ and poured into the rumen via the rumen cannula. The distribution of milk was stopped 6 weeks before the beginning of the first measurement. Each week the ruminal fluid of the defaunated animals was examined in order to verify that they remained free of protozoa.

\subsubsection{Diet}

The four diets given were the same as those given to the growing lambs. The amounts of concentrate were two times as high as those given to the lambs. The grass was administered ad libitum in two diets at $7 \mathrm{~h}$ and $19 \mathrm{~h}$ at the same time as the concentrate. The rams had free access to water and mineralised salt blocks described in the growth trial.

\subsubsection{Experimental design}

The 16 rams were conducted according to two parallel latin square designs (faunated vs. defaunated). Defaunated and faunated rams, placed in metabolism cages and housed in the same room, were isolated with a punch cloth. Each experimental period was composed of 14 days of adaptation to the diet and 10 days of sampling ( 5 days of intake measurement, faeces and 
urine excretions; 3 days for duodenal digesta; 2 days for ruminal liquid).

\subsection{Experimental procedures}

\subsubsection{Growth trial}

Ruminal contents (obtained via an oesophageal tube) from defaunated lambs were examined at the end of each experimental period and found to be free of protozoa. Intake was determined individually from the daily weighing of the amounts of feed offered and refused. Representative samples of the feeds (3 samples / day of the distributed grass) were constituted for chemical analysis. A double weighing (at 24 hour intervals) of the rams was performed. The average daily gain was calculated on the last 15 days of each period.

\subsubsection{Digestion trial}

Intake and apparent digestibility were determined from the daily weighing of the amounts of feeds offered and refused and of the faeces. Representative samples of the feeds ( 3 samples per day) and faeces (10\% of the daily excretion) were constituted for chemical analysis. During these 5 days, daily excretions of urine were also recorded. Urine was daily collected in drums containing sulphuric acid (approximately 1 vol. $\mathrm{H}_{2} \mathrm{SO}_{4}(10 \%)$ per 100 vol. urine). Daily samples of urine were pooled during 5 days for nitrogen determination.

Duodenal digesta flows were estimated according to the double-marker method of Faichney [18] using faecal lignin and polyethylene glycol (peg) as markers of the particulate and liquid phases, respectively. The polyethylene glycol $\left(20 \mathrm{~g} \cdot \mathrm{d}^{-1}\right)$ was continuously infused $\left(200 \mathrm{~mL} \cdot \mathrm{d}^{-1}\right)$ in the rumen using a peristaltic pump. The infusion started 5 days before the beginning of the faeces sampling period. The PEG infusion was stopped at the end of the duodenal digesta sampling period. The mean daily duodenal digesta sample was constituted by taking twelve $100 \mathrm{~mL}$ samples over three consecutive days at (day 1) 0, 6, 12 and $18 \mathrm{~h}$; (day 2) 2, 8, 14 and $20 \mathrm{~h}$; and (day 3) 4, 10, 16 and $22 \mathrm{~h}$ after the morning meal distribution. Each sample was immediately fractionated as follows: $50 \mathrm{~mL}$ were kept to represent whole digesta (WD) and $50 \mathrm{~mL}$ were divided into a liquid-rich phase (LR) and a particle-rich fraction (PR) by squeezing the digesta through a nylon gauze of $150 \mu \mathrm{m}$ pore size. Each fraction was pooled per animal and per diet and was kept frozen, prior to the chemical analysis for organic matter $(\mathrm{OM})$, crude protein $(\mathrm{CP})$, neutral detergent fibre (NDF), acid detergent fibre (ADF), acid detergent lignin (ADL) and purine bases.

The samples of the rumen liquor were taken immediately before the morning meal, and at 3, 6 and $12 \mathrm{~h}$ after feeding, during two consecutive days. Rumen fluid was stored $\left(4{ }^{\circ} \mathrm{C}\right)$ with $\mathrm{H}_{2} \mathrm{SO}_{4}$ (1 vol./50 vol.) prior to ammonia determination.

At the end of each period, the rumen of each animal was manually emptied and the total content was weighed, 3 hours after the distribution of the morning meal. The morning meal was interrupted after 3 hours of free access. The mean retention time (h) of the rumen digesta was estimated as the following: (the amount of lignin in the rumen 3 hours after the morning meal) / (the amount of lignin excreted daily in the faeces divided per 24) [2]. Bacterial samples were isolated from the duodenal LR phase by carrying out two successive centrifugations (800 $g$ and $27000 \mathrm{~g}$ ) as described by Yang [38]. The ratio of the purine bases to the non-ammonia nitrogen (NAN) was calculated with bacterial samples to estimate the microbial nitrogen concentration in the duodenal flow.

\subsection{Chemical analysis}

Dry matter was determined by drying to a constant weight at $60{ }^{\circ} \mathrm{C}$ in a forced draught oven. The samples were ground $(1 \mathrm{~mm})$ prior to chemical determination. 
The samples were ashed for $10 \mathrm{~h}$ at $550^{\circ} \mathrm{C}$. The OM content was determined as the difference between dry and ash weight. The neutral detergent fibre (NDF), acid detergent fibre (ADF) and acid detergent lignin (ADL) were estimated according to the method of Van Soest et al. [32]. Nitrogen concentration was determined using the Dumas combustion method [10]. The purine base was analysed according to Zinn and Owens [39]. Ammonia concentration was estimated in the rumen liquor by distillation and titration. The polyethylene glycol concentration was estimated by spectrophotometry [27].

\subsection{Statistical analyses}

\subsubsection{Growth trial}

Dry matter intake (DMI), feed and energy conversion ratios and average daily gain (ADG) data were analysed by the ANOVA procedure. The means between defaunated and faunated animals on the same diet were compared by the least significant difference test of Tukey, significance was declared at $P<0.05$ [29]. The global model (1) used was:

$$
\begin{gathered}
Y_{i j k l}=\mu+\operatorname{Def}_{j}+\operatorname{Diet}_{k}+\operatorname{Per}_{1}+(\operatorname{Def} \times \\
\text { Diet })_{j k}+\operatorname{Animal}(\text { Def })_{i(j)}+e_{i j k l}
\end{gathered}
$$

where $Y_{i j k l}$ is the observed character for animal i, $\mu$ the global mean, Def the defaunation effect (faunated vs. defaunated, $1 \mathrm{DF}$ ), Diet the diet effect (3 DF), Per the period effect (3 DF), (Def $\times$ Diet) the interaction between the defaunation effect and the diet effect (3 DF), Animal(Def) the animal effect and $\mathrm{e}_{\mathrm{ijkl}}$ represents the unexplained residual error. The defaunation effect was calculated using Animal(Def) as the error term.

Some covariates were integrated into the global model. Hence, the statistical model used to analyse the DMI data took into account the live-weight of the animals (at the beginning of each experimental measurement period) as a covariate. Concerning the ADG the statistical model used took into account the DMI and the animal liveweight (inside the fauna status) as covariates. Concerning feed and energy conversion ratios analysis, the DMI was integrated as a covariate.

\subsubsection{Digestion trial}

ANOVA procedures were used in all statistical analyses [29] and significant differences among means were detected using the least significant difference test of Fisher. The same global model (1) as with the growth trial was used.

The ruminal and total tract digestibility and the mean retention time were analysed using the same model and DMI was integrated as a covariate. Nitrogen intake was used as a covariate in the statistical analyses of the rumen ammonia concentrations, the duodenal nitrogen flow, and nitrogen excretion.

\section{RESULTS}

\subsection{Growth trial}

The forage dry matter intake of faunated animals increased significantly from the D1 diet to the D2 diet. There was no significant difference of forage dry matter intake between the D2 and D4 diets (Tab. II). The forage dry matter intake of the defaunated animals increased significantly from the D2 diet to the D4 diet. The forage dry matter intake was significantly higher with conventional lambs compared with ciliate free lambs $(P<0.01,74.9$ vs. 57.8 , s.e. $=4.0 \mathrm{~g} \cdot \mathrm{kg}$ LW -0.75 ) for the D4 diet. Consequently, total dry matter intake of faunated animals was higher compared with defaunated animals for the D1 $(P<0.05,89.2$ vs. 76.5 , s.e. $=4.1 \mathrm{~g} \cdot \mathrm{kg} \mathrm{LW}-0.75)$ and D4 $(P<0.001$, 88.0 vs. 68.3 , s.e. $=3.9 \mathrm{~g} \cdot \mathrm{kg} \mathrm{LW}^{-0.75}$ ) diets. The amount of energy intake of faunated 
Table II. Growth trial: Effect of defaunation and diet ${ }^{1}$ on intake (dry matter, energy and protein), average daily gain and feed conversion ratios (dry matter and energy) of lambs.

\begin{tabular}{|c|c|c|c|c|c|c|c|c|c|c|c|c|c|c|c|}
\hline & \multicolumn{2}{|c|}{ D1 } & \multicolumn{3}{|c|}{ D2 } & \multirow[b]{2}{*}{ SEM } & \multicolumn{2}{|c|}{ D3 } & \multirow[b]{2}{*}{ SEM } & \multicolumn{2}{|c|}{ D4 } & \multirow[b]{2}{*}{ SEM } & \multicolumn{3}{|c|}{ Significance $^{2}$} \\
\hline & $\mathrm{F}$ & $\mathrm{D}$ & SEM & $\mathrm{F}$ & $\mathrm{D}$ & & $\mathrm{F}$ & $\mathrm{D}$ & & $\mathrm{F}$ & $\mathrm{D}$ & & Def & Diet & Def $\times$ Diet \\
\hline \multicolumn{16}{|l|}{ DM intake $\left(\mathrm{g} \cdot \mathrm{kg} \mathrm{LW}{ }^{-0.75}\right)$} \\
\hline Forage & $38.9^{\mathrm{a}}$ & $32.1^{\mathrm{b}}$ & 2.0 & $60.1^{\mathrm{a}}$ & $52.4^{\mathrm{b}}$ & 1.6 & $65.4^{\mathrm{a}}$ & $59.0^{\mathrm{b}}$ & 1.7 & 70.2 & 65.7 & 2.2 & $* * *$ & $* * *$ & NS \\
\hline Total DM & $85.5^{\mathrm{a}}$ & $77.3^{\mathrm{b}}$ & 2.0 & $87.0^{\mathrm{a}}$ & $79.1^{\mathrm{b}}$ & 1.6 & $82.3^{\mathrm{a}}$ & $76.1^{\mathrm{b}}$ & 1.7 & $77.9^{\mathrm{a}}$ & $71.5^{\mathrm{b}}$ & 2.2 & $* * *$ & $* * *$ & NS \\
\hline Energy intake $\left(\mathrm{UFL} \cdot \mathrm{d}^{-1}\right)$ & $1.04^{\mathrm{a}}$ & $0.95^{\mathrm{b}}$ & 0.02 & $0.92^{\mathrm{a}}$ & $0.85^{\mathrm{b}}$ & 0.01 & $0.83^{\mathrm{a}}$ & $0.77^{\mathrm{b}}$ & 0.02 & 0.71 & 0.67 & 0.02 & $* * *$ & $* * *$ & NS \\
\hline Protein intake ${ }^{3}\left(g \cdot d^{-1}\right)$ & $81.6^{\mathrm{a}}$ & $72.7^{b}$ & 2.0 & $93.1^{\mathrm{a}}$ & $85.8^{\mathrm{b}}$ & 1.6 & $95.7^{\mathrm{a}}$ & $89.9^{\mathrm{b}}$ & 1.7 & 94.2 & 89.3 & 2.2 & $* * *$ & $* * *$ & NS \\
\hline Protein/energy ratio 4 & 77.8 & 76.4 & 1.2 & 100.8 & 100.2 & 1.1 & 117.4 & 117.5 & 1.1 & $131.8^{\mathrm{a}}$ & $137^{\mathrm{b}}$ & 1.4 & NS & $* * *$ & $*$ \\
\hline Average daily gain $\left(\mathrm{g} \cdot \mathrm{d}^{-1}\right)$ & 164.3 & 172.9 & 15.0 & $153.7^{\mathrm{a}}$ & $211.6^{\mathrm{b}}$ & 13.0 & 173.6 & 183.1 & 13.2 & 172.1 & 168.8 & 17.5 & $*$ & NS & NS \\
\hline \multicolumn{16}{|l|}{ Conversion ratio } \\
\hline Feed $\left(g \cdot g^{-1}\right)$ & 6.6 & 5.4 & 1.7 & $7.2^{\mathrm{a}}$ & $4.7^{\mathrm{b}}$ & 1.6 & 6.0 & 5.2 & 1.6 & 5.7 & 5.3 & 1.6 & NS & NS & NS \\
\hline Energy $\left(10^{-3} \mathrm{UFL} \cdot \mathrm{g}^{-1}\right)$ & 6.3 & 5.3 & 1.3 & $6.0^{\mathrm{a}}$ & $4.0^{\mathrm{b}}$ & 0.7 & 4.8 & 4.2 & 0.7 & 4.1 & 4.0 & 1.4 & NS & NS & $*$ \\
\hline
\end{tabular}

${ }^{1}$ Mixed diets composed of fresh Digitaria decumbens grass (28-day age of regrowth) and 4 concentrate mixtures (Soya meal + ground maize); the diets were formulated to provide 4 protein / energy ratios of 80,100, 120 and $140 \mathrm{~g}$ PDIN/UFL on diet D1, D2, D3 and D4 respectively.

$2 *: P<0.05$, **: $P<0.01$, ***: $P<0.001$, NS: $P>0.05$; Def: defaunation effect, Diet: diet effect, Def $\times$ Diet: interaction effect.

D: defaunated animals, F: faunated animals.

${ }^{3}$ Protein truly digestible in the small Intestine (PDIN); ${ }^{4}$ PDIN/UFL.

a, b Different letters in a same row for the same diet correspond to a significant difference $(P<0.05)$. 
and defaunated animals decreased significantly between diets D1 and D4, whereas a significant $(P<0.05)$ increase was observed for protein intake between D1 and D2. Total intake of energy (UFL.kg LW ${ }^{-0.75}$ ) and protein (PDI, g.kg LW ${ }^{-0.75}$ ) was higher with faunated lambs compared with defaunated lambs: 0.074 vs. $0.068 \mathrm{UFL} \cdot \mathrm{kg} \mathrm{LW}^{-0.75}$ and 7.75 vs. $7.20 \mathrm{~g}$ PDI.kg LW ${ }^{-0.75}$, respectively (Tab. II).

The ADG of the faunated animals did not vary according to the increasing protein to energy ratio of the diet whereas, the ADG of the defaunated animals significantly increased between diets D1 and D2 $\left(P<0.05,172.9\right.$ vs. $\left.211.6 \mathrm{~g} \cdot \mathrm{d}^{-1}\right)$. On average for all diets, the average daily gain (ADG, $\mathrm{g} \cdot \mathrm{d}^{-1}$ ) of faunated lambs was significantly lower $(P<0.03)$ compared with that of defaunated lambs $(165.9$ vs. 184.1 , s.e. $=$ $\left.9.3 \mathrm{~g} \cdot \mathrm{d}^{-1}\right)$. Nevertheless, the differences of ADG between conventional and ciliate free animals were only significant with the D2 $\operatorname{diet}(P<0.05,153.7$ vs. 211.6 , s.e. $=$ $\left.13.0 \mathrm{~g} \cdot \mathrm{d}^{-1}\right)$.

Feed conversion ratio and energy conversion ratio of faunated animals $(6.38$, s.e. $=1.6 \mathrm{~g} \cdot \mathrm{g}^{-1}$ and 5.1 , s.e. $=1.510^{-3}$ $\mathrm{UFL} \cdot \mathrm{g}^{-1}$, respectively) did not vary significantly with the diet (Tab. II). A similar trend was observed for defaunated animals $\left(5.3\right.$, s.e. $=0.9 \mathrm{~g} \cdot \mathrm{g}^{-1}$ and 4.4 , s.e. $=1.010^{-3}$ $\mathrm{UFL} \cdot \mathrm{g}^{-1}$, respectively). Concerning defaunated animals, the feed conversion ratio and the energy conversion ratio were significantly lower compared with those of faunated animals only for the D2 diet (6.9 vs. 4.8 , s.e. $=0.5 \mathrm{~g} \cdot \mathrm{g}^{-1}$ and 6.2 vs. 4.3 , s.e. $=0.510^{-3} \mathrm{UFL} \cdot \mathrm{g}^{-1}$, respectively).

Data concerning conventional lambs indicate that in this experiment an amount of $0.71 \mathrm{UF}$ and $81.6 \mathrm{~g}$ of PDI permitted a mean average daily growth of $166 \mathrm{~g} \cdot \mathrm{d}^{-1}$. The theoretical requirement of the experimental lambs for an average daily gain of $250 \mathrm{~g}$ have been estimated by extrapolation to $0.81 \mathrm{UF}$ and $107 \mathrm{~g} \mathrm{PDI}$, taking into account the maintenance requirement of $0.04 \mathrm{UF}$ and $2.4 \mathrm{~g}$ PDI per kg metabolic weight [8].

\subsection{Digestion trial}

\subsubsection{Intake}

Total dry matter intake $\left(\mathrm{g} \cdot \mathrm{kg} \mathrm{LW}{ }^{-0.75}\right)$ of faunated animals decreased significantly from diet $\mathrm{D} 2$ to diet $\mathrm{D} 4$ (85.4 vs. 68.3, s.e. = $4.1 \mathrm{~g} \cdot \mathrm{kg} \mathrm{LW}{ }^{-0.75}$ ) (Tab. III). Concerning defaunated animals there was no effect of the diet on their total dry matter intake. Total dry matter intake was significantly increased $(P<0.01)$ by defaunation (faunated vs. defaunated): 75.1 vs. 84.2 , s.e. $=$ $2.3 \mathrm{~g} \cdot \mathrm{kg} \mathrm{LW}{ }^{-0.75}$ (Tab. III). This increase was due to the increase in intake of Digitaria decumbens $(P<0.05,48.4$ vs. 53.1, s.e. $\left.=2.1 \mathrm{~g} \cdot \mathrm{kg} \mathrm{LW}^{-0.75}\right)$ after defaunation, because the amounts of concentrate distributed were similar.

Whatever the animal status considered, total DM and OM intake $\left(\mathrm{g} \cdot \mathrm{d}^{-1}\right)$ significantly decreased from diet D2 to diet D4, whereas total NDF and ADF intake significantly increased from diet D1 to diet D4. Total CP intake significantly increased only from diet D1 to diet D2 (Tab. III). Total $\mathrm{DM}, \mathrm{OM}$ and ADF intake $\left(\mathrm{g} \cdot \mathrm{d}^{-1}\right)$ were significantly higher for defaunated animals on diet D4 compared to faunated animals, whereas total NDF intake was significantly lower for defaunated animals on the D4 diet (Tab. III). There was no difference of CP intake between defaunated and faunated animals.

\subsubsection{Total tract, ruminal and intestinal digestibility and particle mean retention time}

Total tract digestibility of organic matter of faunated and defaunated animals decreased significantly $(P<0.05)$ between the D3 and D4 diets (Tab. III). A significant increase $(P<0.05)$ of total tract digestibility of $\mathrm{CP}$, for both faunated and defaunated animals, was observed from diet D1 to diet D2. The total tract digestibility of NDF increased significantly from diet D1 to diet D2 for the defaunated animals. No effect of 
Table III. Digestion trial: Effect of defaunation and $\operatorname{diet}^{1}$ on the intake of dry matter (DM), organic matter (OM), crude protein (CP), neutral detergent fibre (NDF), acid detergent fibre (ADF) and apparent digestibility in the total tract (OM, CP, NDF, ADF) of rams.

\begin{tabular}{|c|c|c|c|c|c|c|c|c|c|c|c|c|c|c|c|}
\hline & \multicolumn{2}{|c|}{ D1 } & \multirow[b]{2}{*}{ SEM } & \multicolumn{2}{|c|}{ D2 } & \multirow[b]{2}{*}{ SEM } & \multicolumn{2}{|c|}{ D3 } & \multirow[b]{2}{*}{ SEM } & \multicolumn{2}{|c|}{ D4 } & \multirow[b]{2}{*}{ SEM } & \multicolumn{3}{|c|}{ Significance $^{2}$} \\
\hline & $\mathrm{F}$ & $\mathrm{D}$ & & $\mathrm{F}$ & $\mathrm{D}$ & & $\mathrm{F}$ & $\mathrm{D}$ & & $\mathrm{F}$ & $\mathrm{D}$ & & Def & Diet & Def $\times$ Diet \\
\hline \multicolumn{16}{|c|}{ Intake ( $\left.g \cdot k g L W^{-0.75}\right)$} \\
\hline Total DM & $76.5^{\mathrm{a}}$ & $89.2^{\mathrm{b}}$ & 4.1 & 85.4 & 76.7 & 4.5 & 73.0 & 82.4 & 4.2 & $68.3^{\mathrm{a}}$ & $88^{\mathrm{b}}$ & 3.9 & $* *$ & NS & $*$ \\
\hline \multicolumn{16}{|c|}{ Intake $\left(g \cdot d^{-1}\right)$} \\
\hline Total DM & 1331.0 & 1457.9 & 66.1 & 1509.4 & 1329.1 & 73.1 & 1291.9 & 1350.2 & 67.2 & $1200.4^{\mathrm{a}}$ & $1463.7^{b}$ & 62.8 & NS & NS & $*$ \\
\hline Total OM & 1286.6 & 1416.9 & 65.8 & 1432.7 & 1278.4 & 71.6 & 1220.8 & 1209.6 & 63.2 & $1115.7^{\mathrm{a}}$ & $1209.6^{b}$ & 61.8 & NS & NS & $*$ \\
\hline Total CP & 134.2 & 138.9 & 6.3 & 177.6 & 162.8 & 6.3 & 179.4 & 173.6 & 5.6 & 179.8 & 193.2 & 5.5 & NS & $* * *$ & NS \\
\hline Total NDF & 437.9 & 541.1 & 52.3 & 728.9 & 603.3 & 57.0 & 690.0 & 583.1 & 50.3 & $930.6^{\mathrm{a}}$ & $753.9^{\mathrm{b}}$ & 49.3 & NS & $* * *$ & $*$ \\
\hline Total ADF & 186.8 & 238.9 & 26.4 & 341.2 & 279.4 & 28.9 & 328.9 & 324.7 & 25.4 & $367.4^{\mathrm{a}}$ & $460.8^{b}$ & 24.8 & NS & $* * *$ & $*$ \\
\hline \multicolumn{16}{|c|}{ Total tract digestibility (\%) } \\
\hline $\mathrm{OM}$ & 74.1 & 74.1 & 2.0 & 74.6 & 77.3 & 2.1 & 72.5 & 72.1 & 1.9 & 64.8 & 70.5 & 2.0 & NS & $* * *$ & NS \\
\hline $\mathrm{CP}$ & $54.2^{\mathrm{a}}$ & $63.1^{\mathrm{b}}$ & 2.5 & $65.1^{\mathrm{a}}$ & $72.7^{b}$ & 1.9 & 72.9 & 73.0 & 1.6 & 72.6 & 71.7 & 1.7 & $* *$ & $* * *$ & $*$ \\
\hline NDF & 48.5 & 46.8 & 4.1 & 63.6 & 66.3 & 4.2 & 66.4 & 65.8 & 3.9 & 66.4 & 68.1 & 3.9 & NS & $* * *$ & NS \\
\hline $\mathrm{ADF}$ & 67.5 & 57.7 & 4.0 & 71.3 & 70.8 & 4.1 & 71.9 & 68.9 & 3.7 & 70.1 & 71.7 & 3.7 & NS & NS & NS \\
\hline
\end{tabular}

${ }^{1}$ Mixed diets composed of fresh Digitaria decumbens grass (28-day age of regrowth) and 4 concentrate mixtures (Soya meal + ground maize); the diets were formulated to provide 4 protein / energy ratios of 80,100, 120 and $140 \mathrm{~g}$ PDIN/UFL on diet D1, D2, D3 and D4 respectively.

$2 *: P<0.05$, **: $P<0.01$, ***: $P<0.001$, NS: $P>0.05$; Def: defaunation effect, Diet: diet effect, Def $\times$ Diet: interaction effect.

D: defaunated animals, F: faunated animals.

a, b Different letters in a same row for the same diet correspond to a significant difference $(P<0.05)$. 
Table IV. Digestion trial: Effect of defaunation and $\operatorname{diet}^{1}$ on the ruminal and intestinal digestibility of organic matter $(\mathrm{OM})$, neutral detergent fibre (NDF), acid detergent fibre (ADF) and crude protein $(\mathrm{CP})$, and particle mean retention time in the rumen (hours) of rams.

\begin{tabular}{|c|c|c|c|c|c|c|c|c|c|c|c|c|c|c|c|}
\hline & \multicolumn{2}{|c|}{ D1 } & \multicolumn{3}{|c|}{ D2 } & \multirow[b]{2}{*}{ SEM } & \multicolumn{2}{|c|}{ D3 } & \multirow[b]{2}{*}{ SEM } & \multicolumn{2}{|c|}{ D4 } & \multicolumn{4}{|c|}{ Significance $^{2}$} \\
\hline & $\mathrm{F}$ & $\mathrm{D}$ & SEM & $\mathrm{F}$ & $\mathrm{D}$ & & $\mathrm{F}$ & $\mathrm{D}$ & & $\mathrm{F}$ & $\mathrm{D}$ & SEM & Def & Diet & ef $\times$ Diet \\
\hline \multicolumn{16}{|c|}{ Ruminal digestibility (\%) } \\
\hline $\mathrm{OM}$ & $60.4^{\mathrm{a}}$ & $47.8^{\mathrm{b}}$ & 4.5 & 52.4 & 50.2 & 4.7 & 46.1 & 40.8 & 4.5 & 46.6 & 43.9 & 4.4 & NS & $* *$ & NS \\
\hline NDF & 43.7 & 23.3 & 5.7 & 49.8 & 50.2 & 5.5 & 52.7 & 47.5 & 5.3 & 60.4 & 54.2 & 5.2 & NS & $* * *$ & NS \\
\hline $\mathrm{ADF}$ & 40.2 & 25.8 & 5.5 & 48.9 & 48.8 & 5.4 & 51.9 & 44.6 & 5.2 & 56.7 & 51.7 & 5.1 & NS & $* *$ & NS \\
\hline \multicolumn{16}{|c|}{ Intestinal digestibility (\%) } \\
\hline $\mathrm{OM}$ & 46.6 & 48.7 & 4.9 & 42.5 & 50.9 & 4.7 & 45.6 & 49.8 & 4.5 & $31.6^{\mathrm{a}}$ & $46.9^{\mathrm{b}}$ & 5.4 & $*$ & NS & NS \\
\hline $\mathrm{CP}$ & $47.2^{\mathrm{a}}$ & $64.0^{\mathrm{b}}$ & 3.7 & $58.7^{\mathrm{a}}$ & $70.9^{\mathrm{b}}$ & 3.5 & 67.2 & 69.9 & 3.5 & 59.9 & 63.2 & 3.1 & $* *$ & $* *$ & NS \\
\hline $\mathrm{NDF}$ & 24.9 & 30.7 & 7.0 & 17.0 & 32.0 & 6.5 & 17.0 & 33.9 & 6.5 & $9.4^{\mathrm{a}}$ & $33.8^{\mathrm{b}}$ & 5.9 & $* *$ & NS & NS \\
\hline $\mathrm{ADF}$ & 21.8 & 34.7 & 8.3 & 17.8 & 27.7 & 7.7 & $10.9^{\mathrm{a}}$ & $31.6^{\mathrm{b}}$ & 7.2 & $2.7^{\mathrm{a}}$ & $32.2^{\mathrm{b}}$ & 6.9 & $* *$ & NS & NS \\
\hline \multicolumn{16}{|c|}{ Particle mean retention time in the rumen (hours) } \\
\hline & 37.3 & 36.9 & 4.7 & 33.1 & 26.8 & 4.5 & $41.8^{\mathrm{a}}$ & $20.5^{\mathrm{b}}$ & 4.3 & 46 & 35.1 & 4.2 & $* *$ & NS & NS \\
\hline $\begin{array}{l}\operatorname{mix} \\
100 \\
2 *:\end{array}$ & $\begin{array}{l}20 \mathrm{a} \\
<0 \\
0\end{array}$ & .1. & $P$ & $* * *:$ & 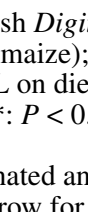 & 0.00 & $>$ & 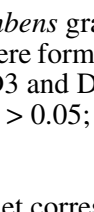 & - D & $f_{2}$ & vide & prot & th) & & ct, \\
\hline
\end{tabular}

the diet on total tract digestibility of ADF was observed. Total tract digestibility of OM, NDF and ADF were not affected by defaunation (Tab. III). On the contrary, total tract digestibility of $\mathrm{CP}$ of faunated animals was lower compared with defaunated animals on diets D1 $(P<0.01,54.2$ vs. 63.1 , s.e. $=2.5 \%)$ and D2 $(P<0.01,65.1$ vs. 72.7 , s.e. $=1.9 \%$ ).

The ruminal digestibility of OM of the faunated animals decreased from diet D1 to D3 $(P<0.05,59.9$ vs. 45.6 , s.e. $=4.2 \%)$ (Tab. IV). No effect of the diet on ruminal digestibility of $\mathrm{OM}$ of the defaunated animals was observed. Ruminal digestibility of NDF and ADF of faunated animals increased from diet $\mathrm{D} 1$ to $\mathrm{D} 2(P<0.05,43.1$ vs. 50.2 , s.e. $=5.3 \%)$ and from diet D1 to
D4 $(P<0.05,40.2$ vs. 56.7 , s.e. $=5.2 \%)$. Concerning defaunated animals, ruminal digestibility of NDF and ADF increased from diet $\mathrm{D} 1$ to $\mathrm{D} 2(P<0.05,27.3$ vs. 49.4 , s.e. $=5.9 \%$ and $P<0.05,25.8$ vs. 48.8 , s.e. $=$ $5.8 \%$, respectively).

Intestinal digestibility of OM, NDF and ADF of faunated and defaunated animals did not vary significantly with the diet, whereas intestinal digestibility of $\mathrm{CP}$ was increased significantly $(P<0.05)$ from diet D1 to D2, for faunated animals (Tab. IV). Defaunation significantly increased $(P<0.05)$ intestinal digestibility of $\mathrm{OM}$, $\mathrm{NDF}, \mathrm{ADF}$ and $\mathrm{CP}$. The differences of intestinal digestibility of $\mathrm{OM}, \mathrm{NDF}$ and ADF between faunated and defaunated animals were significant $(P<0.05)$ for 
the D4 diet, whereas differences of intestinal digestibility of $\mathrm{CP}$ were significant $(P<0.05)$ for the D1 diet.

The diet had no effect on the mean retention time of fibre particles in the rumen (Tab. IV). This was significantly higher $(P<0.01)$ with faunated rams compared with defaunated rams (40 vs. 30 , s.e. $=2 \mathrm{~h}$ ). The differences between faunated and defaunated animals were significant $(P<0.05)$ for diet D3.

\subsubsection{Nitrogen digestion}

Rumen ammonia concentration $\left(\mathrm{NH}_{3}\right)$ increased significantly with the $\mathrm{P} / \mathrm{E}$ ratio of the diet $(P<0.001)$, for both faunated and defaunated animals (Tab. V). Defaunation significantly $(P<0.001)$ decreased $\mathrm{NH}_{3}$ $\left(185.9\right.$ vs. 147.1 , s.e. $\left.=7.4 \mathrm{mg} \mathrm{N} \cdot \mathrm{L}^{-1}\right)$. The differences between faunated and defaunated animals were significant with all the diets, except with diet D1.

The duodenal non-ammonia nitrogen (NAN) and the duodenal microbial nitrogen (MN) flows, of both faunated and defaunated animals, decreased with the $\mathrm{P} / \mathrm{E}$ ratio of the diet $(P<0.001)(\mathrm{Tab} . \mathrm{V})$. These decreases were significant $(P<0.001)$ from diet D3 to D4, for both faunated and defaunated animals. Duodenal NAN and MN flows were significantly increased $(P<0.001)$ by defaunation $(23.07$ vs. 27.58 , s.e. $=0.9 \mathrm{~g} \mathrm{NAN} \cdot \mathrm{d}^{-1}$; and 12.3 vs. 14.9, s.e. $=0.5 \mathrm{~g} \mathrm{MN} \cdot \mathrm{d}^{-1}, P<0.001$, respectively). The differences of duodenal NAN flow observed between defaunated and faunated animals were significant $(P<0.05)$ for diet D3, while differences were significant $(P<0.05)$ for diets D2 and D3 for duodenal MN flow (Tab. V).

The microbial protein synthesis efficiency (MSE, g MN synthesised per $\mathrm{kg}$ of organic matter apparently degraded in the rumen (OMADr)) decreased significantly from diet D3 to D4, for both faunated and defaunated animals. MSE increased $(P<0.001)$ with defaunation $(20.3$ vs. 31.0 , s.e. $=2.2 \mathrm{~g} \mathrm{MN} \cdot \mathrm{kg}^{-1} \mathrm{OMADr}$ ). The differ- ences between faunated and defaunated animals were significant $(P<0.001)$ on diet D3 (Tab. V).

The diet had no effect on the nitrogen faecal excretion. The nitrogen faecal excretion was significantly higher $(P<0.05)$ with conventional animals compared with ciliate-free animals ( 8.8 vs. 7.7 , s.e. $=0.36 \mathrm{~g}$ $\mathrm{N} \cdot \mathrm{d}^{-1}$ ). The differences between faunated and defaunated animals were significant $(P<0.05)$ with the D1 diet (Tab. V).

The nitrogen urinary excretion increased $(P<0.05)$ while the amounts of Soya meal in the diet increased, for both faunated and defaunated animals. This increase was significant for the faunated animals between diets D2 and D3, and for the defaunated animals between diets D3 and D4. The nitrogen urinary excretion decreased significantly $(P<0.05)$ with defaunation (7.26 vs. 5.72 , s.e. $\left.=0.49 \mathrm{~g} \mathrm{~N} \cdot \mathrm{d}^{-1}\right)$. There was no interaction $(P=0.80)$ between defaunation and the $\operatorname{diet}(\mathrm{Tab} . \mathrm{V})$.

\section{DISCUSSION}

The theoretical daily requirements of the experimental animals needed to reach their potential growth $\left(250 \mathrm{~g} \cdot \mathrm{d}^{-1}\right)$ are $0.8 \mathrm{UF}$ and $106 \mathrm{~g}$ PDI. On this basis, it can be presumed that the energy amount would be a limiting factor of growth only when faunated lambs consumed the D4 diet. Moreover, no variation of growth was observed for faunated lambs, for which the energy intake decreased between diet D1 and D2 whereas no variation of growth and protein intake have been observed. Consequently, it can be presumed that protein intake was the first limiting factor of their growth. Concerning the ciliate-free lambs, the amount of energy intake was a limiting factor of growth for the D3 and D4 diets. Moreover, the energy intake would be overestimated because of the decrease in digestibility generally observed on ciliate-free lambs [17] as illustrated with the present digestion trial. 
Table V. Digestion trial: Effect of defaunation and diet ${ }^{1}$ on nitrogen intake, rumen ammonia concentration, nitrogen duodenal flow, microbial synthesis efficiency, faecal and urinary nitrogen excretion of rams.

\begin{tabular}{|c|c|c|c|c|c|c|c|c|c|c|c|c|c|c|c|}
\hline & \multicolumn{2}{|c|}{ D1 } & \multirow[b]{2}{*}{ SEM } & \multicolumn{2}{|c|}{$\mathrm{D} 2$} & \multirow[b]{2}{*}{ SEM } & \multicolumn{2}{|c|}{ D3 } & \multirow[b]{2}{*}{ SEM } & \multicolumn{2}{|c|}{ D4 } & \multirow[b]{2}{*}{ SEM } & \multicolumn{3}{|c|}{ Significance $^{2}$} \\
\hline & $\mathrm{F}$ & $\mathrm{D}$ & & $\mathrm{F}$ & $\mathrm{D}$ & & $\mathrm{F}$ & $\mathrm{D}$ & & $\mathrm{F}$ & $\mathrm{D}$ & & Def & Diet & Def $\times$ Diet \\
\hline Nitrogen intake $\left(\mathrm{g} \mathrm{N} \cdot \mathrm{d}^{-1}\right)$ & 19.2 & 20.0 & & 29.2 & 24.5 & & 29.9 & 27.8 & & 29.6 & 32.5 & & $* *$ & $* *$ & NS \\
\hline Rumen ammonia $\left(\mathrm{mg} \mathrm{N} \cdot \mathrm{L}^{-1}\right)$ & 112.2 & 110.1 & 16.5 & $182.8^{\mathrm{a}}$ & $140.0^{\mathrm{b}}$ & 14.6 & $201.7^{\mathrm{a}}$ & $155.7^{\mathrm{b}}$ & 14.0 & $247.0^{\mathrm{a}}$ & $182.6^{\mathrm{b}}$ & 13.2 & $* *$ & $* *$ & NS \\
\hline \multicolumn{16}{|l|}{ Duodenal flow $\left(\mathrm{g} \cdot \mathrm{d}^{-1}\right)$} \\
\hline Non ammonia nitrogen & 28.2 & 31.8 & 2.2 & 24.1 & 28.6 & 1.8 & $21.7^{\mathrm{a}}$ & $27.8^{\mathrm{b}}$ & 1.7 & 17.1 & 20.5 & 1.8 & $* * *$ & $* * *$ & NS \\
\hline Microbial nitrogen & 16.4 & 18.7 & 1.3 & $12.9^{\mathrm{a}}$ & $16.3^{\mathrm{b}}$ & 1.1 & $10.8^{\mathrm{a}}$ & $14.5^{\mathrm{b}}$ & 1.0 & 8.5 & 9.2 & 1.0 & $* * *$ & $* * *$ & NS \\
\hline \multicolumn{16}{|l|}{ Microbial synthesis efficiency } \\
\hline (g MN.kg-1 OMADR) & 31 & 36.8 & 5.5 & 17.9 & 30 & 4.5 & $17.2^{\mathrm{a}}$ & $40.5^{\mathrm{b}}$ & 4.1 & 14.9 & 16.9 & 4.2 & $* * *$ & $* *$ & NS \\
\hline Faecal nitrogen $\left(\mathrm{g} \mathrm{N} \cdot \mathrm{d}^{-1}\right)$ & 8.8 & 7.4 & 0.8 & $10.2^{\mathrm{a}}$ & $6.7^{b}$ & 0.7 & 8.1 & 7.5 & 0.7 & 8.1 & 9.2 & 0.7 & $*$ & NS & * \\
\hline Urinary nitrogen $\left(\mathrm{g} \mathrm{N} \cdot \mathrm{d}^{-1}\right)$ & 5.9 & 3.9 & 1.5 & 6.0 & 4.7 & 1.0 & 8.0 & 5.8 & 0.9 & 9.1 & 8.4 & 0.9 & $*$ & $*$ & NS \\
\hline
\end{tabular}

${ }^{1}$ Mixed diets composed of fresh Digitaria decumbens grass (28-day age of regrowth) and 4 concentrate mixtures (Soya meal + ground maize); the diets were formulated to provide 4 protein / energy ratios of 80, 100, 120 and $140 \mathrm{~g}$ PDIN/UFL on diet D1, D2, D3 and D4 respectively.

$2 *: P<0.05$, **: $P<0.01$, ***: $P<0.001$, NS: $P>0.05$; Def: defaunation effect, Diet: diet effect, Def $\times$ Diet: interaction effect.

$\mathrm{D}$ : defaunated animals, $\mathrm{F}$ : faunated animals.

a, b Different letters in a same row for the same diet correspond to a significant difference $(P<0.05)$. 
In our experimental context, with the D1 and D2 diets, the level of energy was sufficient to maximise growth and could bring to light differences between faunated and defaunated lambs. Nevertheless, significant differences appeared only with the D2 diet. This significant difference of growth could be attributed to the significant difference of protein availability between animals $(18 \%)$ as indicated with the digestion trial. In fact, the availability of protein was underestimated with the ciliate-free lambs as illustrated by the estimation of the duodenal protein flow for the D1 diet in the digestion trial. Concerning the D1 diet, the level of growth of the lambs must have been limited by the level of their protein intake. Moreover, in theory the starch rich diets like D1, for which the amount of energy is scarcely a limiting factor of growth, had to generate large differences of growth between faunated and defaunated animals. As reported by Eadie et al. [16] a high amount of starch contributes to totally or partially eliminate protozoa in the rumen. The mean level of starch was $68 \%$ in the D1 diet. Consequently, a part of the positive effect of the partial elimination of protozoa could exist with the conventional animals consuming starch rich diets. This could be supported by the low difference of nitrogen duodenal flow and rumen ammonia concentrations observed in our results between faunated and defaunated rams consuming D1.

No difference of growth was observed between defaunated and faunated lambs consuming diets D3 and D4. With the ciliate-free lambs, both the lower theoretical amount of energy intake and the decrease of dry matter digestibility (digestion trial) contributed to decrease the energy availability. The growth observed with the D4 diet could indicate that no or a low effect could be observed with animals consuming a cell wall rich diet, because although the decrease of digestible organic matter intake is low, the total amount of energy of these diets must not be sufficient to maximise growth or to generate a difference between faunated and defaunated animals.

The depressing effect of defaunation on the ruminal and total tract digestibility of organic matter and fibre is a classical result $[17,24,37]$. Nevertheless, thanks to a compensatory digestion in the intestine as illustrated by the digestion trial, the nutritional impact of defaunation on digestion was low. The intake of digestible OM of the latter was $10,6,8$ and $0 \%$ lower than those of conventional lambs for diets D1, D2, D3 and D4 respectively. The ratio metabolic energy / digestible energy ratio may be higher with ciliate free lambs. Indeed, we observed lower urinary $\mathrm{N}$ losses with defaunated animals and, according to the literature data, the methane production is lower with ciliate free animals [26, 33, 37].

The better feed and energy conversion ratios observed with the ciliate-free lambs for the D2 diet were in good agreement with their intake (dry matter, energy) and growth. Moreover, the better feed conversion ratio after defaunation may be mainly attributed to the higher yield of metabolic utilisation of absorbed nutrients, for maintenance and growth [5]. Indeed, the duodenal nitrogen flow increased in ciliate free rams, and both the dietary and the microbial nitrogen flows contributed to this increase $[23,28,30]$. On the one hand, in ciliate-free animals, due to a lower proteolytic activity in the rumen, the ruminal degradation of dietary protein decreased and consequently the flow of intestinal by pass dietary protein increased [25]. The lower ammonia concentration observed with ciliate-free rams underlined this lower proteolytic activity [19]. On the other hand, the increase of the microbial nitrogen duodenal flow is reflected by the better microbial synthesis efficiency mainly due to a decrease of protozoa predation upon bacterial nitrogen [13, 17, 19].

Few trials give an indication on nitrogen urinary excretion $[21,25,28,36]$. Our data shows a lower nitrogen urinary excretion in ciliate-free animals as already observed 
[17]. This decrease varied (7 to $33 \%$ ) with the amount of protein in the diet. These results of nitrogen urinary excretion were in good agreement with those of rumen ammonia concentration, for which lower values were observed with ciliate-free animals. A higher efficiency of the nitrogen metabolism by the ruminal ecosystem of ciliate-free animals may explain this result, due to a lower $\mathrm{N}$ recycling in these animals.

In this experiment, the study of interactions between the diet and defaunation is not easy to interpret. Indeed, forage consumption of defaunated lambs was lower than faunated ones, so for the same diet the metabolic values of the diet could differ between the defaunated and faunated animals. Moreover, comparisons would have been easier with iso-energy diets. Nevertheless, our data underlined the varying effect of defaunation and the diet interaction. Significant and positive effect of defaunation on growth, appeared when these conditions were gathered: the availability of energy nutrients from the rumen and protein at the duodenum were under the requirements of the animals to maximise their growth; the energy intake is not the first limiting nutritional factor; and the P/E ratio of the diet is low.

\section{CONCLUSION}

The positive effect of defaunation on the average daily gain of lambs has been clearly established in this experiment. The hypothesis that the protein to energy ratio of the diet is the major factor of variation of the effect of defaunation on animal growth performance seems plausible, since energy nutrients is not the first limiting factor.

\section{ACKNOWLEDGEMENTS}

The authors would like to thank L. Philibert, S. Calif, P. Despois, C. Césaire and F. Nipeau, for their technical collaboration to this work. This work was supported by the "Région Guadeloupe" and the European Union (FEOGA funding).

\section{REFERENCES}

[1] Abou Akkada A.R., El-Shazly K., Effect of absence of ciliate protozoa from the rumen on microbial activity and growth of lambs, Appl. Microbiol. 12 (1964) 381-390.

[2] Archimède H., Aumont G., Saminadin G., Deprès E., Despois P., Xandé A., Effect of urea and saccharose on intake and digestion of a Digitaria decumbens hay by Black Belly sheep, Anim. Sci. 69 (1999) 403-410.

[3] Becker E.R., Everett R.C., Comparative growths of normal and infusoria-free lambs, Am. J. Hygiene 11 (1930) 362-370.

[4] Bird S.H., Production from ciliate-free ruminants, in: Nolan J.V., Leng R.A., Demeyer D.I. (Eds.), The role of protozoa and fungi in ruminant digestion, Pennambul books, Armidale NSW 2351, Australia, 1989, pp. 233 246.

[5] Bird S.H., Hill M.K., Leng R.A., The effects of defaunation of the rumen on the growth of lambs on low-protein-high-energy diets, Brit. J. Nutr. 42 (1979) 81-87.

[6] Bird S.H., Leng R.A., The effects of defaunation of the rumen on the growth of cattle on low-protein high-energy diets, Brit. J. Nutr. 40 (1978) 163-167.

[7] Bird S.H., Seccombe M., A comparative study of faunated lambs and lambs reared from birth free of ciliate protozoa, Proceedings of the Australian Society of Animal Production, Armidale NSW, Australia, Animal Production in Australia, 1998, 22, p. 391.

[8] Bocquier F., Thériez M., Sheep, in: Jarrige R. (Ed.), Ruminant nutrition: recommended allowances and feed tables, INRA Editions, Paris, 1989, pp. 153-167.

[9] Borhami B.E., El-Shazly K., Abou Akkada A.R., Ahmed I.A., Effect of early establishment of ciliate protozoa in the rumen on microbial activity and growth of early weaned buffalo calves, J. Dairy Sci. 50 (1967) 1654 1660

[10] Buckee G.K., Determination of total nitrogen in barley, malt and beer by Kjeldahl procedures and the Dumas combustion method collaborative trial, J. Inst. Brew. 100 (1994) 57-64.

[11] Christiansen W.C., Woods W., Burroughs W., Ration characteristics influencing rumen protozoal populations, J. Anim. Sci. (1963) 984 988.

[12] Coleman G.S., The importance of rumen ciliate protozoa in the growth and metabolism of the host ruminant, Int. J. Anim. Sci. 3 (1988) 75-95. 
[13] Demeyer D.I., Van Nevel C.J., Influence of substrate and microbial interaction on efficiency of rumen microbial growth, Reprod. Nutr. Dev. 26 (1986) 161-179.

[14] Demeyer D.I., Van Nevel C.J., Van de Voorde G., The effect of defaunation on the growth of lambs fed three urea containing diets, Arch. Tierernährg. 32 (1982) 595-604.

[15] Eadie J.M., Hobson P.N., Effect of presence or absence of ciliates on the total rumen bacterial counts in lambs, Nature 193(1962) 503505 .

[16] Eadie J.M., Hyldgaard-Jensen J., Mann S.O., Reid R.S., Whitelaw F.G., Observations on the microbiology and biochemistry of the rumen in cattle given different quantities of a pelleted barley ration, Brit. J. Nutr. 24 (1970) 157-177.

[17] Eugène M., Archimède H., Sauvant D., Quantitative meta-analysis on the effects of defaunation of the rumen on growth, intake and digestion in ruminants, Livest. Prod. Sci. 85 (2004) 81-97.

[18] Faichney G.J., The use of markers to measure digesta flow from the stomach of sheep fed once daily, J. Agric. Sci. (Camb.) 94 (1980) 313-318.

[19] Firkins J.L., Allen M.S., Oldick B.S., StPierre N.R., Modeling ruminal digestibility of carbohydrates and microbial protein flow to the duodenum, J. Dairy Sci. 81 (1998) 33503369.

[20] Fujihara T., Todoroki M., Nakamura N., The effect of rumen protozoa on the urinary excretion of purine derivatives in goats, J. Agric. Sci. 140 (2003) 101-105.

[21] Ikwuegbu O.A., Sutton J.D., The effect of varying the amount of linseed oil supplementation on rumen metabolism in sheep, Brit. J. Nutr. 48 (1982) 365-375.

[22] Ivan M., Veira D.M., Kelleher C.A., The alleviation of chronic copper toxicity in sheep by ciliate protozoa, Brit. J. Nutr. 55 (1986) 361367.

[23] Jouany J.P., Thivend P., Influence of protozoa on nitrogen digestion in the ruminant, IVth international symposium on protein in metabolism and nutrition, les colloques de l'INRA, Route de St Cyr, 78000 Versailles, France, INRA Editions, 1983, 16 (II), pp. 287-290.

[24] Jouany J.P., Ushida K., The role of protozoa in feed digestion, Asian-Australas. J. Anim. Sci. 12 (1998) 113-128.

[25] Koenig K.M., Newbold C.J., McIntosh F.M., Rode L.M., Effects of protozoa on bacterial nitrogen recycling in the rumen, J. Anim. Sci. 78 (2000) 2431-2445.

[26] Kreuzer M., Kirchgessner M., Müller H.L., Effect of defaunation on the loss of energy in wethers fed different quantities of cellulose and normal or steam flaked maize starch, Anim. Feed Sci. Technol. 16 (1986) 233-241.

[27] Malawar R., Powel D.D., Improved turbidimetric analyses of polyethylene-glycol using an emulsifier, Gastroenterology 53 (1967) 250-256.

[28] Punia B.S., Leibholz J., Faichney G.J., The role of rumen protozoa in the utilisation of paspalum (Paspalum dilatatum) hay by cattle, Brit. J. Nutr. 57 (1987) 395-406.

[29] SAS, SAS/STAT User's Guide: statistics, version 6, SAS Inst. Inc., Cary, North Carolina, USA, 1988.

[30] Ushida K., Jouany J.P., Thivend P., Role of rumen protozoa in nitrogen digestion in sheep given two isonitrogenous diets, Brit. J. Nutr. 56 (1986) 407-419.

[31] Van Nevel C.J., Demeyer D.I., Van de Voorde G., Effect of defaunating the rumen on growth and carcass composition of lambs, Arch. Anim. Nutr. 35 (1985) 331-337.

[32] Van Soest P.J., Robertson J.B., Lewis B.A., Methods for dietary fiber, neutral detergent fiber, and non starch polysaccharides in relation to animal nutrition, J. Dairy Sci. 74 (1991) 3583-3597.

[33] Vermorel M., Jouany J.P., Effects of rumen protozoa on energy utilisation by wethers of two diets based on ammonia treated straw supplemented or not with maize, Asian-Australas. J. Anim. Sci. 2 (1989) 475-476.

[34] Vermorel M., Feed evaluation for ruminants. II. The new energy systems proposed in France, Livest. Prod. Sci. 5 (1978) 347-365.

[35] Vérité R., Journet M., Jarrige R., A new system for the protein feeding of ruminants: the PDI system, Livest. Prod. Sci. 6 (1979) 349367.

[36] Whitelaw F.G., Eadie J.M., Bruce L.A., Shand W.J., Methane formation in faunated and ciliate-free cattle and its relationship with rumen volatile fatty acid proportions, Brit. J. Nutr. 52 (1984) 261-275.

[37] Williams A.G., Coleman G.S., The rumen protozoa, Springer-Verlag, London, 1992

[38] Yang W.Z., Étude de la cinétique de la colonisation des aliments dans le rumen des moutons. Conséquence sur la compartimentation de la biomasse et de la dynamique à la sortie du rumen dans le cas de différents types de rations, Ph.D. thesis, Université Blaise Pascal, Clermont Ferrand II, n ${ }^{\circ}$ 307, France, 1992.

[39] Zinn R.A., Owens F.N., A rapid procedure for purine measurement and its use for estimating net ruminal protein synthesis, Can. J. Anim. Sci. 66 (1986) 157-166. 